Journal of Teacher Education for Sustainability, vol. 18, no. 1, pp. 111-126, 2016

\title{
Autonomous Learning for English Acquisition in Blended e-Studies for Adults within the Context of Sustainable Development
}

\author{
Ināra Bojāre \\ Daugavpils University, Latvia
}

\begin{abstract}
Personality integration and self-realisation in the global economy and coevolution with multilingual cultural environment of sustainable learning society by means of technologies actualise the paradigm shift in science, and create the necessity for transdisciplinary research to resolve the problem of transformation of the system of values in the context of acquisition of languages. The research aims to create a holistic model of autonomous learning for English acquisition in blended environment of e-studies in the context of adult non-formal education. The research is done on the basis of the holistic paradigm of the science. Holistic methodology is used for investigation of the holistic system. The research resulted in creating the holistic model and working out the recommendations to facilitate of the transformation of the system of values of participants at the programmes of English acquisition of adult non-formal education. The results of the research are significant for developing the concept of autonomous learning.
\end{abstract}

Keywords: autonomous learning, autonomous English acquisition, pedagogical support, technological support, limit factors, ecoautonomy

\section{Introduction}

The article presents the results of the completed research on autonomous learning for English acquisition in blended e-studies for adults within the context of sustainable development. It is a holistic structurally divisible and functionally indivisible pedagogically facilitated learning process, organisation form, value and English learner's learning approach in technologically supported learning environment with dual properties of transition and sustainability that promotes the development of learners' experience and collaboration in the environment and interaction with it.

The research aims to create a holistic model of autonomous learning for English acquisition in blended environment of e-studies in the context of adult non-formal education. To reach the aim, it is necessary to answer the question: how does autonomous learning influence the transformation of the system of values and integration into the environment?

The hypothesis of the research is that the depth and the structure of the comprehension of the process of autonomous learning for English acquisition, which is used 
for connecting the pedagogical and technological facilitation for developing an individual's experience and competence, are important to create a holistic model of autonomous learning in English acquisition in blended environment of e-studies in the context of adult non-formal education.

The criteria suggested for argumentation of the hypothesis make a system of mutually connected values that includes relationships between participants of the learning process based on responsibility; English learning strategies describing an individual's learning experience and competence; interaction in the environment - collaboration.

\section{The Framework of the Research}

The research is conducted on the basis of the holistic paradigm of the science. It supposes the system approach for the cognition of the complex world that substitutes its fragmental cognition. The development has been considered as increasing the complexity of interdependent phenomena and processes. The ontology of the holistic scientific research shows the evolution of the holistic approach from monism to parts of the system and their properties and to investigation of the whole and the properties of the whole where the whole is more than the sum of its parts. Being part of the system refers to its nature and does not mean a specific spatial or causal arrangement of the parts (Esfeld, 2004; 11).

The paradigm shift towards the general paradigm of sustainable development has actualised evolutional philosophy, the system approach and methodology of complex processes in the science. Sustainable development is connected with the holistic approach in educational research in Latvia (Salīte 1998; Badjanova \& Iliško, 2015). Its content aspect is a systemic approach where integral personality can be seen as a system itself (Wilber 2006; Badjanova 2013, 2014).

From a holistic approach, learning implies not only training skills, but also includes strategies of their use (Badjanova \& Iliško, 2015). It means that autonomous language learning directed by teacher can also include strategies and techniques that learners could use to apply their learning competences. It enhances one's self-direction for the development of learning experience.

Person's environmental positioning develops from his/ her social positioning and, like a biocentric positioning, is an indicator of a sustainable quality in a relationship (Gedžūne, 2015) between a person and the nature. The global context of society is ensured by technologies (Huckle, 1996). It creates the necessity of the person's integration and self-realisation in multilingual cultural environment, but technologies create opportunities for the person's inclusion in e-learning society (Vìtolina, 2015).

It is clear that eco[logical] and eco[nomical] sustainability are two different kinds of global development of sustainability: sustainability in the time frame and sustainability in the frame of the system. The first is a deformative relationship of a person and the nature. I. Salite (2015) analyses the evolution of cooperative relations that are viewed both as a complex process and as a complex system of established relationships.

They develop from natural relationships to complex and linear co-evolutionary relations that deepen un-sustainability. Cooperative complex and non-linear relations developing sustainability are the mission of pedagogy where the highest humane ideals are not lost. Co-evolution and deeper understanding of interrelated orientation to sustainable development are the mission of pedagogy based on values (Salite, 2015). 
The ecological paradigm in education is promoted by taking into account classroom and technologically supported learning environment that turns the attention of pedagogical practitioners towards changes and sustainability. Plurilingual approach instead of multilingual approach to the acquisition of foreign languages reflects the paradigm shift in language acquisition (EC [European Council], 2001) that aims at its practical use without an interpreter.

The theoretical framework of the study is based on the conception of evolutionary philosophy (Corning, 2005; Laszlo, 1991, 2009; Lāslo, 2011); the approach of holistic philosophy (Quine, 1980); the convergence of humanistic and natural sciences following from the General System Theory (Bertalanffy von, 1968); ecophilosophy that supports the investigation of the depth of the whole (Naess, 1989); theory of Everything (Vilbers, 2011); change Theory, directions and forces (Fulans, 1999); the approach of autonomous learning (Роджерс, 2004) in language acquisition (Holec, 1981) and adult non-formal education (Knowles, 1975), and strategies of learning (Pintrich 2002; Oxford, 1990, 2003, 2011); transformative Learning Theory (Mezirow 1981, 2000; Brookfield, 2000) and facilitation of integrated learning (Esbjörn-Hargens, 2011). Developing the system approach and the complex methodology of scientific investigation (Laszlo \& Krippner, 1998; Степин, 2003; Буданов, 2007) reaches the holistic approach and the investigation of the holistic systems (Esfeld, 2004) in the research.

The characteristic of adult learners is based on andragogy (Knowles, 1970); characteristics of orders of consciousness (Kegan, 1994) and integral model of consciousness (Vilbers, 2011). The statements of European Council $(2001,2006)$ about the acquisition of foreign languages, the thesis of the Theory of e-Learning (Nichols, 2003) are taken in account. The environmental approach considers learners' relationships with the environment (Iriste \& Katane, 2015).

Increasing the complexity of the phenomenon and the process of autonomous learning shows that radical autonomous learning with maximal individual's responsibility for reaching the learning goal evolves into the dialog between a learner and facilitator in self-directed learning (Knowles, 1975). The relationship between the subject and self-developing poly-subjective environment (Лепский, 2014) is the next level of the development expressing self-determined learning in group in the learning environment of blended e-studies.

Interdependent phenomena with autonomous learning are a person's identity that develops from Self-identity to We-identity (Tennant, 2006) and Eco-identity in the process of individualisation, socialisation and ecologisation. It follows that social ethics of learning is based on a person's right to be taught, individual - on one's own responsibility for reaching the learning goals (Vilbers, 2011), as well as environmental - on interactivity.

A person's sticking to lower levels of the development means an environmental crisis (Vilbers, 2011) that shows the lack of the ability to integrate into the environment. The aim of holistic education is an integrated personality, but the inclusion into the system of lifelong education through programmes of adult non-formal education to a great extent continues the tradition of directed process of learning.

The design of the research presented in Figure 1 shows that a teacher's directed English learning experience and competence are based on self-regulated learning (SRL) where a teacher is responsible for the achievement of the learning goal. Learning strategies and metastrategies promote the learner's autonomy in the framework of SRD (Oxford, 
2011; Wenden 1991; Flavell, 1979; Weinstein \& Mayer, 1986; Pintrich 2002), but the use of technologies aims at supporting the acquisition of language skills.

In the beginning, the development of learning experience and competences was considered self-directed learning (SDL) facilitated by the facilitator in adult non-formal education (Knowles, 1975; Beitler, 2005) that would be implemented by autonomous language learning (Holec, 1981). Its implementation actualises the transformation of values by critical reflection on previous assumptions and beliefs (Mezirow, 1981). Nevertheless, it was concluded that the humanistic theory of autonomous learning (Роджерс, 2004; Маслоу, 2004; Knowles, 1970, 1975) in the context of learning of the foreign languages (Holec, 1981) had substituted the process of individuals' learning by a teaching method (Deimante-Hartmane, 2013) where the autonomy had the meaning of inside learning.

Technological facilitation emphasizes self-controlled acquisition of language skills (Benson, 2013). It has been found out that technological approach defines autonomous English acquisition in blended e-studies as the linear transitional process from directed English learning in the classroom to self-organised learning (SOL) in the virtual learning environment (Bojāre, $2015 \mathrm{a}, \mathrm{b}$ ). Another way is the sustainable holistic process of autonomous language acquisition in blended e-studies. It follows from the dual properties of a part (Vilbers, 2011), i.e. a part and the whole. Therefore the acquisition of language skills is facilitated in humanistic approach and technologically, but the learning process is reduced to teaching method of autonomous English acquisition in the learning environment of blended e-studies.

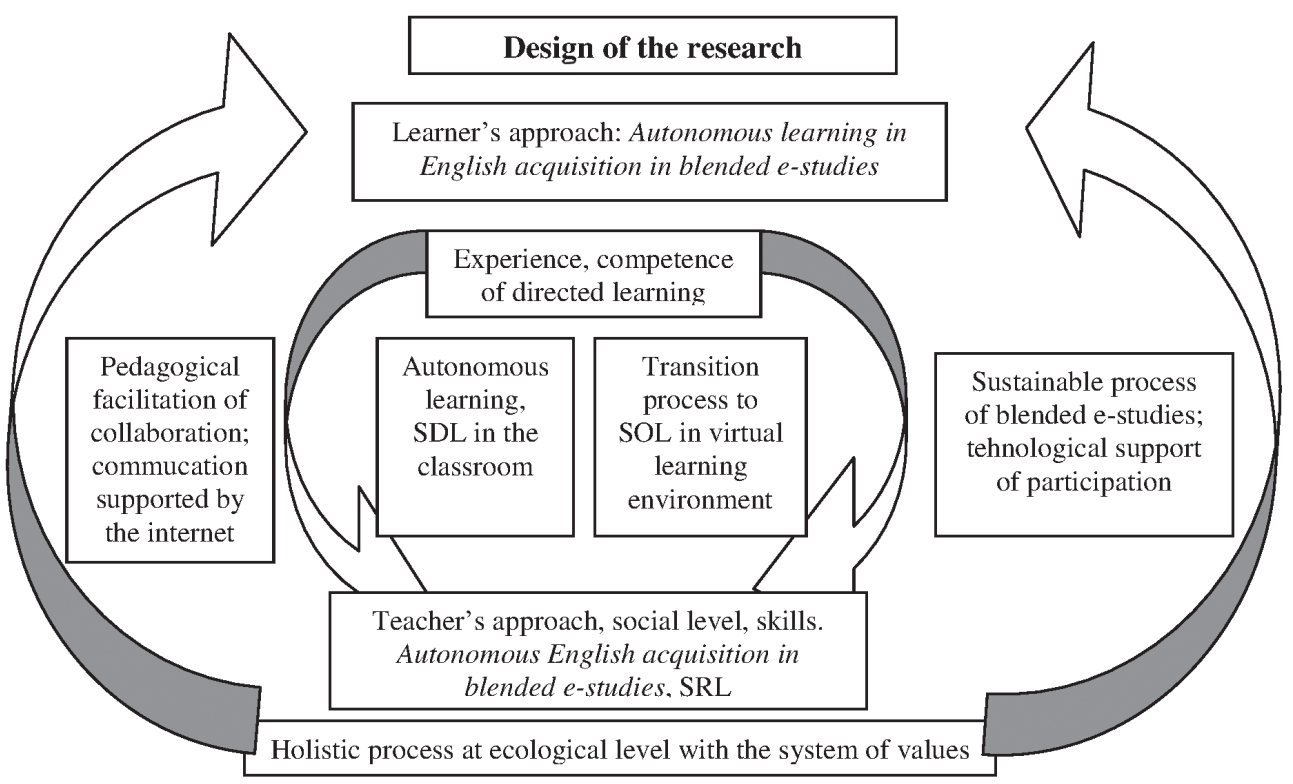

Figure 1. Design of the research

This process is developed to the renewed whole of autonomous learning in the context of learning of foreign languages - Autonomous learning for English acquisition in blended e-studies at the next stage of the research. Firstly, it is an English learner's approach to the development of experience and competence of learning. Secondly, the 
English learner's cognitive participation in the learning process is supported by technologies by means of design of programmes, the opportunities of content delivery, design and its acquisition (Ortega \& Sánchez-Villalón, 2006; Warschauer, 1996; Benson \& Voller, 1997; Can, 2012; Benson, 2013). It promotes the development of individualised competence of language. Thirdly, communication supported by the internet and pedagogical facilitation is directed to promoting collaboration, for example, by organisation of learning societies and synchronous lessons.

Therefore, the development of learning environment supported by information and communication technologies (ICT) and the internet broadens the social level of self-directed learning facilitated by the facilitator to the environmental level of learning with an emphasis on self-determined learning in group that includes SDL and SRL (Rubene, 2009). Democratic relationships with the facilitator change to relationships with the democracy of the group. The transformation of the system of values is necessary for improving the quality of the choice (Mezirow, 1981).

The correlation of the systems is ensured by the environment. The impulse, given by the development of ICT and their use in education, is favoured for overcoming social restrictions and promoting the development of sustainable society on a global scale. The globalisation promotes the integration of a person in global economic environment and technologically supported interaction with social, cultural and natural environment where the acquisition of foreign languages plays an important role.

\section{Methodology}

The general method of transdisciplinary research is the content analysis of theoretical literature aimed at working out its scientific substantiation and modelling. The method of modelling is used for the visualisation of the function, the structure and the process of the holistic system. The system approach and the methodology of complex processes for using transdisciplinary and integrative connections in blended e-learning environment of adult non-formal education are used for the production of the holistic model. Holistic interpretation of the empirical results is done according to the top-down conceptualisation of holism, which begins with the whole and properties of the whole (Esfeld, 2004).

The research was performed in the period from 2009 to 2016. Its empirical method is compound quantitative and qualitative research followed by the action research. The empirical research includes:

- qualitative methods for collecting data - a narrative, a survey and SWOT analysis in the action research,

- methods of data analysis - qualitative (content analysis, encoding of obtained data, grouping and interpretation),

- quantitative methods of data analysis - quantitative statistical methods of primary data analysis and descriptive statistics (graphical visualisation of the data, determination of the frequency of the data, multidimensional statistical analysis - cluster analysis, methods of processing the data (varimax rotation method for factor analysis, calculation Cronbach Alpha coefficient for the calculation of the reliability of the distinguished factors, definition of the statistical significance of the clusters, creating the classification tree of the accepted decisions) by using SPSS 22.0 version of data processing software. 
The qualitative method of non-structured narrative about the experience of acquisition of foreign languages is used in the qualitative part of the research. The quantitative data are collected using the questionnaire. SWOT (strengths, weaknesses, opportunities and threats) analysis, with weaknesses excluded in the factor analysis of the quantitative research, is used in the action research. The SWOT analysis of limit factors is essential in the process of changes; therefore, the complex investigation of all the factors is not necessary. They are expressed by empirically determined metacognitive strategies: the personal factor, the factor of participation, the factor of organisation, the factor of evaluation, the factor of knowledge, the factor of skills and the factor of development. The recommendations are worked out on the basis of the data analysis. The testing of the reliability of the research results is based on the triangulation of the methods.

The holistic interpretation of the empirical results (Figure 1) followed by using the complex methodology and creating a model based on humanistic approach (Bojāre, 2011). Its shortcoming was the insufficient attention to the technically supported learning environment. The use of synergetic methodology for inquiring of the process of changes (Буданов, 2007) in education (Marulevska, 2011) resulted in creating the synergetic model (Bojāre, 2015a, b). It allowed the researcher to recognise the role of technologically supported learning environment in the development of learners' learning experience and competence, and showed two ways of facilitation of transformation of values.

The first way is connected with the linear transformation of values from directed English acquisition in classroom environment to its self-organised acquisition in the learning environment supported by the internet. The second way improves the quality of the choice through the transformation of the system of values in the sustainable learning process of e-studies.

Holistic approach refers to the ecological level of sustainable education where the system of values is changing. It allows for the use of the method of facilitation of the transformation of the system of values for developing an integrated English learner in the learning environment of blended e-studies with direct and virtual interaction. Holistic methodology is appropriate for the investigation of holistic systems (Esfeld, 2004). A holistic system is an open self-developing dynamic nonlinear creative and adaptive evolutionary system the nuclear of which consists of individual autonomy, the social level - of social autonomy and the ecological level - of ecological autonomy.

The ecological autonomy in subject-centred education is autonomy in the circumstances of interdependence. The ecological autonomous learning corresponds to the holistic level of education where the environment is taken into account. The self-actualisation for integration and self-realisation in the environment are the preconditions of cooperation for the development of eco-identity and personality because the main principles of evolutionary systems are to be and to become (Буданов, 2007).

Ecologisation broadens the concept of socialisation from a positive inclusion of a person in the society to the inclusion into the environment where the teacher's facilitation, collaboration with the group and technological support are important. Coevolution with the environment provides the new level for the traditional approach of autonomous learning of foreign languages (Holec, 1981) and autonomous and self-directed learning (Роджерс, 2004; Knowles, 1970, 1975; Beitler, 2000, as quoted in Beitler, 2005). The conceptual knowledge oriented model for the comprehension of self-directed learning in e-studies created by L. Song and J. R. Hill (2007) is studied before the creation of the research model. 
The holistic system of autonomous learning for the acquisition of English in blended e-studies in the context of adult non-formal education consists of the holistic systemic whole of an English learner, learning organisation and open learning environment. It is a part of the common system. The connection between them is substantiated by the opportunities of the internet supported learning environment that reaches the mezo-level of the environment of the Universe. The cosmos is chosen as the metaphor of the whole that is modelled by the geometrical fractal as the model of a living thing where a fractal creates the fractal alike to itself. The substantiation of fractals of life and scientific action is provided by A. Broks (Broks, 2000). Didactic fractal is developed from that by L. Jonane (Jonāne, 2009).

The holistic model unites the individual's learning dimension (strategies for acquisition of the English language), the social dimension of teaching (the organisational forms of learning process based on different levels of responsibility) and the transdimension of the facilitated learning environment (pedagogical and technological) of blended e-studies in the common system. The readiness of the participants of the learning process of autonomous learning for the acquisition of English in blended e-studies to change their attitude is the foundation of the transformation of the system of values that determines the development of the experience and competence in the acquisition of foreign languages.

The criteria of the readiness for autonomous learning in the process of autonomous learning for the acquisition of English in blended e-studies include the relationships between the participants of the learning process expressed by the organisational forms of the learning process based on different levels of responsibility (self-regulated, selfdirected and self-determined learning); the peculiarities of the learner's learning competence expressed by cognitive and metacognitive strategies; interaction and self-determination in the classroom, virtual environment and blended e-studies.

The research instrument includes three levels reflecting the research dimensions. The research model is shown in Figure 2. Visual division of circle fractal is the most appropriate visual form for the research model. The circles are substituted by the squares to simplify their representation by means of computer graphics. The steps of the pedagogical facilitation around the $7^{\text {th }}$ metacognitive strategy and technological support around the $2^{\text {nd }}$ one are shown at an enlarged scale.

The model shows the transformation of the system of values from self-regulated learning in the classroom to self-directed learning in open learning environment supported by the internet. Further, two scenarios are possible. The first is the linear development of experience and competence for acquiring English that is possible by the transition from learning in the closed classroom environment to self-organised action of learning the English language in the open virtual learning environment. The second is the change of the direction of nonlinear development to self-determined learning in the blended learning environment of e-studies supported by the internet.

Pedagogical facilitation is accessible for the facilitation of development and collaboration, and technological support is accessible for the process of content acquisition and development of language skills by promoting cognitive participation. The completion of English learners' groups in non-formal education is assumed to be a sensitive moment for changes (a point of bifurcation). Synergy is the mechanism that ensures the functionality of all values of the holistic system.

Pedagogical facilitation of metacognitive strategy of development is implemented in six steps at English acquisition programmes of adult non-formal education. They are: 
(1) investigation of learners, (2) the analysis and modelling of changes of the system of values, (3) dividing participants into groups, (4) the determination of the kind (pedagogical, technological, the internet) and direction of the facilitation (facilitation by using the metacognitive strategies, consultation for acquisition of the learning content and language skills, information about learning opportunities in the learning environment supported by technologies and the internet), (5) creating the environment for psychological facilitation in blended e-studies, (6) awareness of learning opportunities, comprehension and elimination of the threats that might prevent from using these opportunities.

Technological support includes the means of communication and content delivery provided by the internet, the design of the content and the means of its individualisation, the means of self-monitoring of acquisition of the content, the means of receiving additional materials, the means of knowledge systematisation, the means of training language skills and other means that promote the development of individualised competence of language and collaboration.

New values include the previous values and implement the aim of holistic education an integrated learner of English. Such a person synthesizes the system of values of the social level, including self-regulated learning, and one's own system of values, including self-directed learning, into the system of values of the environmental level, including self-determined learning.

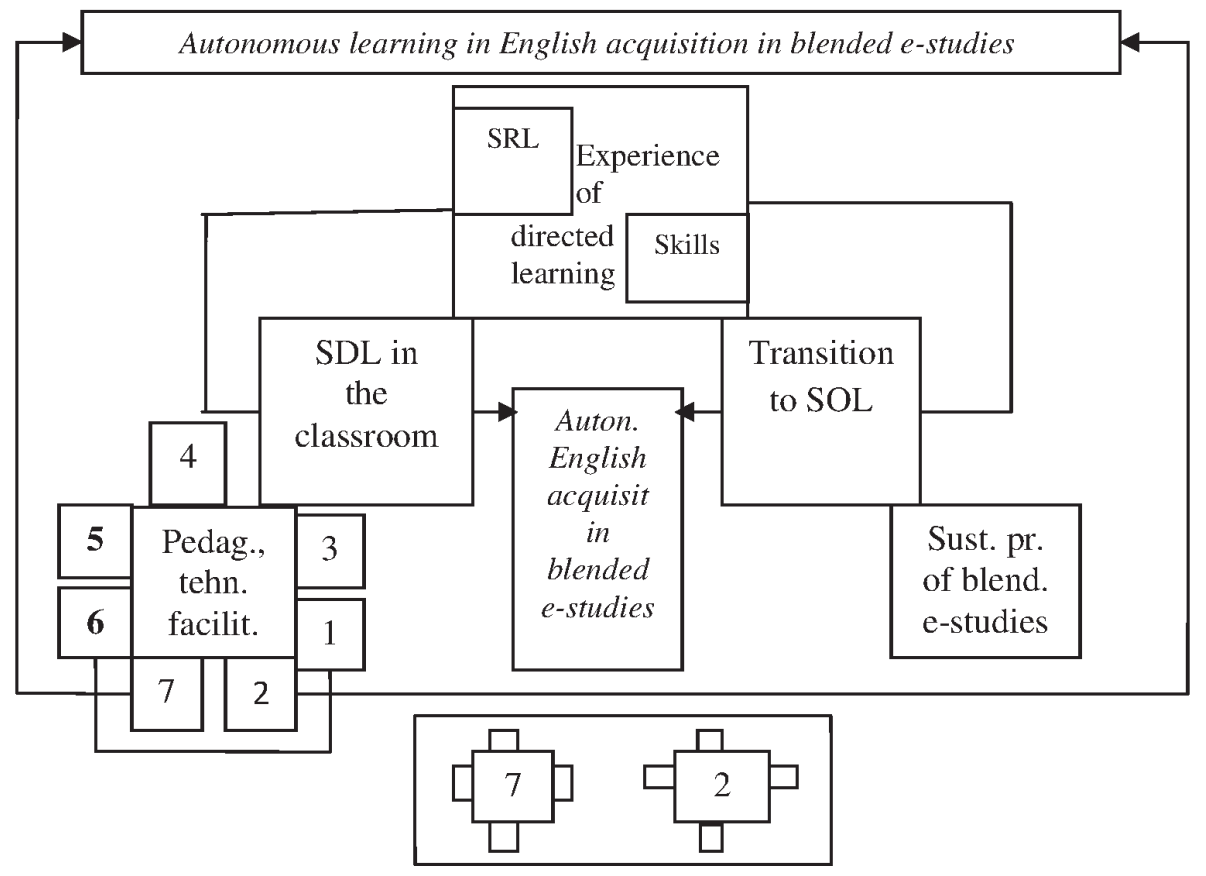

Figure 2. Process model for the facilitation of autonomous learning for the acquisition of English in blended-e-studies, where

1-7 metacognitive strategies;

2 with a square - pedagogical support;

2 - metacognitive strategy of development; 7 with a square - technological support.

7 - metacognitive strategy of participa-

tion for reaching the learning goal; 
The pedagogical function of investigation of the attitude of the participants of English programmes in adult non-formal education is their self-reflection about their own learning; the comprehension of learning possibilities for improving the quality of the choice and removing threats hampering the implementation of these opportunities. Ecological autonomy expresses collaboration in technologically supported environment with polysubjective social environment. Ecological autonomous learning is the right to use learning opportunities and the responsibility for developing learning experience and competence in blended e-studies for the integration in multilingual learning society.

\section{Results of the Research and Discussion}

The empirical part of the research consists of qualitative research, quantitative research and action research. The research basis and results are described in the article presenting the results of autonomous acquisition of English in blended e-studies by adults investigated as a process of transition from directed learning of English in the classroom to self-organised acquisition of English in virtual learning environment (Bojāre, $2015 \mathrm{a}, \mathrm{b})$.

The design of the empirical research arises from the change of the conception of the research presenting autonomous learning for the acquisition of English in blended e-studies as the holistic process that gives the new perspective for the interpretation of the data obtained.

The qualitative research involved five participants, 210 respondents were involved in the quantitative research and different numbers of people participated in three cycles of the action research. The participants of the qualitative research are learners interested in the acquisition of English with rich experience of acquisition of other foreign languages.

Non-probability sampling of respondents was chosen for the quantitative research on the basis of the principle of accessibility. It consisted of volunteers who were ready to take part in the face-to-face research and the survey implemented by means of e-mails. Real participants of English acquisition programmes of adult non-formal education were invited to be the respondents of the research, but their number was insufficient for the research. After that teachers, librarians and parents of schoolchildren as potential participants of the programmes were involved.

The participants of the action research were chosen depending on the results of the quantitative research. Forty-six participants $\left(\mathrm{N}_{1}=46\right)$ were involved in the first cycle. They were the participants of English acquisition programmes of adult non-formal education. Thirty-two of them took part in the second cycle of the research $\left(\mathrm{N}_{2}=32\right)$, four facilitators $\left(\mathrm{N}_{3}=3\right)$ took part in the third cycle (Bojāre, 2015b).

Forty-six questionnaires of the first cycle and 35 working lists of SWOT analysis of the participants of English programmes and their facilitators were analysed. Out of them, 12 working lists of SWOT analysis of the second cycle and 3 individual and 2 pair work SWOT analyses of the third cycle were analysed according to the determined sensitive limit factors of English acquisition. Thus the results of the research were obtained by carrying out the qualitative, quantitative and action research.

The qualitative research aims to create an instrument (a questionnaire) for the quantitative research. The method of narratives was used in the qualitative part of the research where its participants described their experience of acquisition of foreign 
languages. It resulted in a unique set of stories showing a person's developmental adjustment to contemporary multilingual world. An important finding of the qualitative research was a personal six-step self-directed model of foreign language acquisition practised by one participant of the research (Bojāre, 2013).

The quantitative part of the research aims to make a typology of respondents according to their attitude towards the value of SRL, SDL and self-determined learning in classroom and virtual learning environment; to determine sensitive limit factors for promoting learners' positive attitude towards autonomous learning for the acquisition of English in blended e-studies; to create a questionnaire for practical use in programmes of non-formal education.

It was carried out by the method of the survey. The main feature of the research instrument was a three-level questionnaire indicating the level of teaching, learning and learning environment. It was based on the results of the content analysis of the narratives. The data obtained by 5-point Likert-type Self-directed English acquisition readiness scale (SDEARS) in blended e-studies (Bojāre, 2013) were mathematically analysed using the 22.0 version of SPSS software. The quantitative statistical methods of primary data analysis and descriptive statistics with graphical visualisation of the data were used for the presentation of the research results.

The quantitative research resulted in reducing the number of indicators from 306 to 126 and creating a short form of the questionnaire. It can be used for practical selfevaluation of participants and dividing them into groups within the programmes of adult non-formal education. The restriction of the scale is insufficient inclusion of collaborative learning because of the responsibility integration of teachers, learners and groups in virtual language acquisition.

The results of the quantitative part of the research show that only education and professional belonging are meaningful for dividing the respondents into groups. Decision making depends on the respondents' social and professional role and on their level of education. Two groups revealed tree preferred stable forms of learning process - learning directed by the teacher or autonomous learning, but one group expressed an uncertain opinion.

It consisted mostly of the participants of English acquisition programmes of adult non-formal education. They were chosen for further inquiry by SWOT analysis of inquired factors for the facilitation of the transformation of the system of values. The action research aimed to determine the possibilities of the facilitation of the sensitive limit factors expressed by the metacognitive strategies for the development of the learners' learning experience and competence.

The participants were inquired by the short form of the questionnaire (Bojāre, Ignatjeva, 2014) in the first cycle of the action research and the validity of the questionnaire was practically checked. After that they analysed the proposed methodological factors by the SWOT analysis individually, in pairs and in groups in the second cycle. The SWOT analysis was done by the facilitators in the third cycle.

The personal factor - F1 in Figure 3, the factor of involvement - F2, the factor of organisation - F3, the factor of evaluation - F4, the factor of knowledge - F5, the factor of skills - F6 and the factor of development - F7 were determined by the factor analysis during the quantitative research. The working lists contained the strengths of factors in the classroom and virtual learning because their weaknesses were removed as 
a result of the factor analysis. The participants of the action research described the opportunities to use them and wrote why those opportunities could not be used.

The first interpretation of the data obtained was done from the point of view of harmonic and general development of a personality (Bojāre, 2014), but it did not fit exactly in the system approach. Their reinterpretation was done on the basis of sensitive factors. The factors are expressed by metacognitive strategies. Metacognitive strategy of skills (working with learning materials, developing listening skills, translation) is the most understandable strategy for the participants of the action research with 3.58 points on average (see Figure 3).

Traditionally, it is pedagogically and technologically facilitated and corresponds to the traditional pedagogical approach and strong paradigm of sustainable development. It strengthens the knowledge and information society that is based on innovative economics.

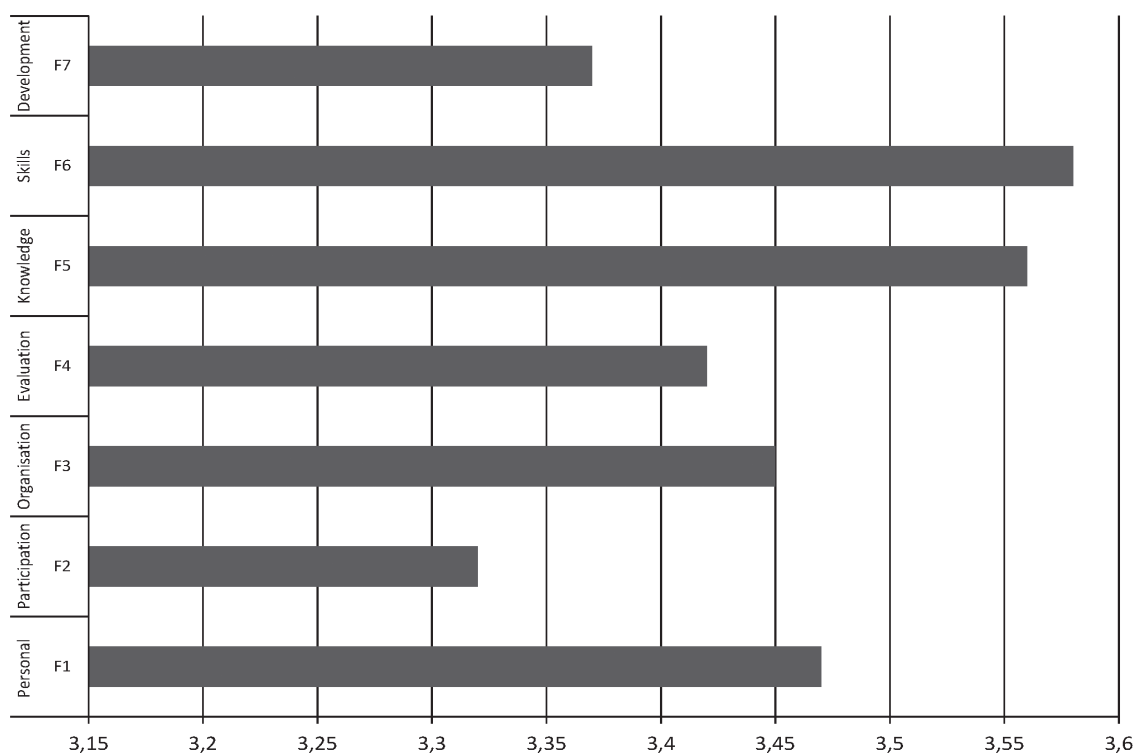

Figure 3. Evaluation of metacognitive strategies

The metacognitive strategy of participation, for opening the whole for its developing and fractal dividing, has the lowest evaluation -3.32 points. The metacognitive strategy of development strengthens weak or deep humanistic paradigm of sustainable development of the society. It is the metacognitive strategy that has the second lowest evaluation 3.37 points.

The metacognitive strategy of participation is a less understandable factor (selecting methods and strategies for performing the task, making tables about learned topics and grammar rules, making mind maps and layouts about topics and grammar rules learned). The metacognitive strategy of development includes writing a letter, writing a creative essay, and a general investigation of the topic.

Pedagogical facilitation of the metacognitive strategy of development and technological support of metacognitive strategy of participation lead to new pedagogical approach and deep paradigm of complex sustainable development. Pedagogical process 
of e-studies is supported by the internet that broadens collaboration and promotes the development of the learning society.

Pedagogical facilitation of metacognitive strategy of development would promote creativity and transformation of other factors by the mechanism of synergy in six steps mentioned in the holistic model of autonomous learning for the acquisition of English in blended e-studies.

The validity of the research was verified by the methodological triangulation. The validity of the research instrument was checked by comparing it with the European Language Portfolio for adults (Dalbina, Grinberga, 2006) and practically in the action research. The validity of the research data was ensured by using two forms of research instrument and qualitative data collection. The validity of the research was based on the holistic paradigm of science, grounding the design of the practical research upon the results of the previous parts of the research and seeking for the adequate and contemporary interpretation of the obtained data.

It is recommended to facilitators of English acquisition programmes of adult nonformal education to take into account learners' education, social and professional role in groups and change the direction of the pedagogical facilitation for the development of learners' learning experience and competence by facilitating the metacognitive strategies of participation and development.

The future direction of the practical research is the use of the model by carrying out the action research in other groups of English programmes of adult non-formal education for developing research methodology; investigation of the group of librarians as the most autonomous learners and their role in facilitation of groupmates for their integration into the environment.

The research instrument should be improved by including the methodological factor of collaboration because of the integration responsibilities of teachers, the learners and groups for reaching the learning goals in virtual learning environment. The future direction of the theoretical investigation is connected with the fourth dimension of time and temporalisation for an individual's integration and self-realisation in time.

\section{Conclusions}

The created holistic model of autonomous learning for the acquisition of English in blended environment of e-studies in the context of adult non-formal education shows more holistic comprehension of the deepness and the structure of the complexity of the process. Its systemic peculiarities determine its natural integration in the processes of sustainable education that is essential for the phenomenon of sustainability. The results of the research show that such a process of learning action in the acquisition of foreign languages creates changes in learners' system of values. They include the relationships between the participants of the learning process based on the responsibility and the strategies of acquisition of English. They define learner's experience and competence of learning influenced by the participation in virtual learning environment. The development of language skills is technologically and pedagogically facilitated. It is recommended to implement the pedagogical facilitation by means of metacognitive strategy of development for broadening the learners' experience and competence, for promoting the learners' interaction in and with the learning environment supported by the internet. The results 
of the research are significant for developing the concept of autonomous learning from radical autonomous learning and the social level of self-directed learning to environmental level of self-determined learning in the group in the context of sustainable education.

\section{References}

Badjanova, J. (2013). Primary school teachers' views on a holistic approach to facilitating the acquisition of musical cultural values. Journal of Teacher Education for Sustainability, 15 (2), 78-90. DOI: 10.2478/jtes-2013-0003.

Badjanova, J. (2014). Holistic approach to facilitating the acquisition of musical cultural values: primary education teachers' views. Saarbrøcken: LAP LAMBERT Academic Publishing.

Badjanova, J. \& Iliško, I. (2015). Holistic approach as viewed by the basic school teachers in Latvia. Discourse and Communication for Sustainable Education, 6, 132-140. DOI: 10.1515/dcse-2015-0010.

Beitler, M. A. (2005). Strategic organizational learning: A practitioner's guide for managers and consultants. Greensboro, USA: PPI.

Benson, P. (2013). Teaching and researching: autonomy in language learning. London, New York: Routledge Taylor \& Francis Group.

Benson, P. \& Voller, P. (1997). Autonomy and independence in language learning. London: Longman.

Bertalanffy von, L. (1968). General system theory: foundations, development, applications. Worchester: Clark University Press.

Bojāre, I. (2014). Autonomous English acquisition in blended e-studies for adults for sustainable development: Active Research. In Sabiedrïba, integrācija, izglìtība: Starptautiskās zinātniskās konferences materiāli [Society, integration, education: Proceedings of the International Scientific Conference], 2, 23-24 May 2014, 291299. Rēzekne: Rēzeknes Augstskola.

Bojāre, I. (2015a). Autonomous English acquisition in blended e-studies for adults for sustainable development: implementation of the synergetic model of transformation of the values. Sabiedrïba, integrācija, izglìtība: Starptautiskās zinātniskās konferences materiāli [Society, integration, education: Proceedings of the International Scientific Conference], 4, 22-23 May 2015, 322-333. Rēzekne: Rēzeknes Augstskola. DOI: org/10.17770/sie2015vol4.409.

Bojāre, I. (2015b). Autonomous English acquisition in blended e-studies for adults for sustainable development: transformation of values. In Rural Environment. Education. Personality. (REEP). Proceedings of the 8th International Scientific Conference, 8, 15-16 May 2015, 415-422. Jelgava, Latvia University of Agriculture.

Bojāre I. (2013). Empirical checking of criteria of the self-directed English acquisition readiness scale in blended e-studies for adults: qualitative research. In U. Harkonen (Eds.) Reorientation of teacher education towards sustainability through theory and practice: Proceedings of the 10th International JTEFS/BBCC conference Sustainable development. Culture. Education, 7, 22-25 May 2012, 233-243. Joensuu: University of Eastern Finland.

Bojāre I. (2011). Self-directed english acquisition in blended e-studies for adults: Criteria of a scale. Journal of young Scientists: CD, 2(35), 4-10. Šiauliai: Šiauliai University. 
Bojāre, I., \& Ignatjeva, S. (2014). Autonomous English acquisition in blended e-studies for adults for sustainable development: Quantitative research. In Rural Environment. Education. Personality. (REEP): Proceedings of the 7th International Scientific Conference, 7, March, 42-49. Jelgava: The Latvia University of Agriculture, Institute of Education and Home Economics.

Broks, A. (2000). Izglītības sistemologija [The systemology of Education]. Rīga: RaKa. Brookfield, S. D. (2000). Transformative learning as ideology critique. In J. Mezirow and Associates (Eds.) Learning as transformation. Critical perspectives on a theory in progress, 125-148. San Francisco: Jossey-Bass.

Can, T. (2012). Promoting learner autonomy through virtual learning environments. Akdeniz Language Studies Conference. Retrieved from http://www.iusanalkampus. com/Yayinlar/Ingilizce_Yayin_1.pdf

Corning, P. A. (2005). Holistic darwinism. Chicago, London: The University of Chicago Press.

Dalbiņa D., Grīnberga I., Jundze I., et. al. (2006). European language portfolio for adults. Riga: Council of Europe, Riga Public Service Language Centre.

Deimante-Hartmane, D. (2013). Vidusskolas vecāko klašu skolènu vispārējo patstāvīgās mācǐšanās prasmiu pilnveide anglu valodas mācību procesā: Promocijas darbs [Improving of general secondary school pupils' independent learning skills in the English language learning process: Doctoral thesis]. Liepāja: Liepājas Universitāte.

Esbjörn-Hargens, S. (2011). Integral teacher, integral students, integral classroom: Applying integral theory to education. Retrieved May 6, 2016, from http://nextstep integral.org/wp-content/uploads/2011/04/Integral-Education-Esbjorn-Hargens.pdf

Esfeld, M. (2004). Philosophical holism. Retrieved from http://www.unil.ch/files/live// sites/philo/files/shared/EOLSS-PhilHolism03.pdf

Eiropas Padome [EP]. Valodas politikas nodaļa. (2006). Eiropas kopīgās pamatnostādnes valodu apguvei: mācišanās, mācǐšana, vērtēšana [The Common European Framework of Reference for Languages]. Rīga: Madonas poligrāfists.

European Council [EC]. Language Policy Division. (2001). The Common European Framework of Reference for Languages. Cambridge: Cambridge University Press.

Flavell, J. H. (1979). Metacognition and cognitive monitoring: A new area of cognitivedevelopmental inquiry. American Psychologist, 34, 906-911.

Fulans, M. (1999). Pārmaiņu spēki: izglītības reformu virzieni [Change Forces: Probing the Depths of Educational Reform]. Riga, Zvaigzne ABC.

Gedžūne, I. (2015). Identification as incentive to care: Pre-service teachers orientation towards inclusion in nature. Discourse and Communication for Sustainable Education, 6, 110-126. DOI: 10.1515/dcse-2015-0008.

Holec, H. (1981). Autonomy and foreign language learning. Oxford: Pergamon Press. Pergamon.

Huckle, J. (1996). Realizing sustainability in changing times. In J. Huckle \& S. Sterling (Eds.), Education for sustainability, 3-17. London: Earthscan Publications Ltd.

Iriste, S. \& Katane, I. (2015). Prospective hospitality managers competence as integral part of competitiveness. Rural Environment. Education. Personality. (REEP). Proceedings of the 8th International Scientific Conference, 8, 15-16 May 2015, 42-49. Jelgava, Latvia University of Agriculture. 
Jonāne, L. (2009). Didaktiskais fraktālis. In 50. starptautiskās zinātniskās konferences materiali [Proceedings of the 50th International Scientific Conference of Daugaupils University]. Retrieved from http://dukonference.lv/raksti_pdf/Jonane+.pdf

Kegan, R. (1994). In over our heads: The mental demands of modern life. Cambridge, MA: Harvard University Press.

Knowles, M. S. (1970). Modern practice of adult education: Andragogy versus pedagogy. Chicago: Follett Publishing Company, Association Press.

Knowles, M. (1975). Self-directed learning. New York: Association Press.

Laszlo, A. \& Krippner, S. (1998). Systems theories: Their origins, foundations, and development. In: J. S. Jordan (Ed.), Systems theories and apriori aspects of perception, 126, 47-74. Amsterdam: Elsevier Science.

Laszlo, E. (1991). The New evolutionary paradigm. New York: Gordon and Breach Science Publishers.

Laszlo, E. (2009). WorldShif 2012: Making green business. New politics \& higher consciousness work together. Rochester, Vermont: Inner Traditions.

Lāslo, E. (2011). Zinātne un akašas lauks [Science and the Akashic Field: An Integral Theory of Everything]. Riga: Jumava.

Marulevska, K. T. (2011). The interdisciplinary dialogue as a path to evolutionary growth of the pedagogical knowledge. Scientific Research, 9, 1-14. Blagoevgrad, Bulgaria: South-West University "Neofit Rilsky".

Mezirow, J. (1981). A critical theory of adult learning and education. Adult Education, $32,3-24$.

Mezirow, J. (2000). Learning to think like an adult: Core concepts of transformation theory. In J. Mezirow \& Associates (Eds.) Learning as transformation, 3-34. San Francisco: Jossey-Bass.

Naess, A. (1989). Ecology, community, and lifestyle: Outline of an ecosophy. Cambridge, UK: Cambridge University Press.

Nichols, M. (2003). A theory for e-Learning. Retrieved from http://home.tiscali.nl/ schopmanlanden.nl/Papers/LearningTheory.html

Ortega, M. \& Sánchez-Villalón P. P. (2006). An interactive blended environment for language learning: AIOLE. In F. J. García et al., (Eds.), Virtual Campus 2006 Postproceedings. Selected and Extended Papers. Retrieved from http://ceur-ws.org/ Vol-186

Oxford, R. L. (1990). Language learning strategies: What every teacher should know. Boston: Heinle \& Heinle.

Oxford R. L. (2003). Language learning styles and strategies: an overview. Learning Styles \& Strategies. Oxford: GALA.

Oxford, R. (2011). Teaching and researching: language learning strategies. Upper Saddle River, NJ, USA: Longman. Pearson.

Pintrich, P. R. (2002). Future challenges and directions for theory and research on personal epistemology. In B. Hofer \& P. R. Pintrich (Eds.). Personal epistemology. The psychology of belief about knowledge and knowing, 389-414. Mahwah, NJ: Lawrence Erlbaum Associates.

Quine, W. V. O. (1980). Two dogmas of empiricism. Cambridge, Massachusetts: Harvard University Press.

Rubene, Z. (2009). Kritiskā domāšana mūsdienu izglìtības filozofijā [Critical Thinking in nowadays Philosophy of Education]. Retrieved from http://www.iac.edu.lv/kd_ old/kas_ir_KD.htm 
Salite, I. (1998). An ecocentric paradigm: An important tool for teachers of environmental education. Australian Journal of Environmental Education 14, 81-85.

Salite, I. (2015). Searching for sustainability in teacher education and educational research: Experiences from the Baltic and Black Sea Circle Consortium for educational research. Discourse and Communication for Sustainable Education, 6, 2129. DOI: $10.1515 /$ dcse-2015-0002.

Song, L. \& Hill, J. R. (2007). A conceptual model for understanding self-directed learning in online environment. Journal of Interactive Online Learning, 6 (1), 27-42.

Tennant, M. (2006). Psychology and adult learning. New York: Routledge and Taylor Franciss Group.

Vilbers, K. (2011). İsa visaptverošā vēsture [A Breef History of Everything]. Rīga, Jumava.

Vìtoliņa, Ie. (2015). E-inclusion process and societal digital skill development. Discourse and Communication for Sustainable Education, 6, 86-94. DOI: 10.1515/dcse-20150006.

Warschauer, M. (1996). Computer assisted language learning: an introduction. In Fotos S. (Ed.), Multimedia language teaching, 3-20. Tokyo: Logos International.

Weinstein, C. E. \& Mayer, R. E. (1986). The teaching of learning strategies. In M. Wittrock (Ed.), Handbook of research on teaching, pp. 3, 15-327). New York, NY: Macmillan.

Wenden, A. L. (1991). Learner strategies for learner autonomy. London: Prentice-Hall International.

Wilber, K. (2006). Integral spirituality. A startling new role for religion in the modern and postmodern world. Boston: Shambhala Publications.

Буданов, В.Г. (2007). Методология синергетики в постнеклассической науке и в образовании. Москва: Издательство Л КИ.

Лепский, В.Е. (2014). Становление субъектно-ориентированного подхода в контексте развития представлений о научной рациональности. In B. И. Аршинова \& И. Т. Касавина (Eds.), Наука и социальная картина мира [Science and social Picture of the world], 392-420. Москва: Альфа-М.

Роджерс, К. (2004). Взгляд на психотерапию. Становление человека [On becoming a person: a therapist's view of psychotherapy]. Киев: PSYLIB.

Степин, В.С. (2003). Саморазвивающиеся системы и постнеклассическая рациональность [Self-developing systems and postnonclassical rationality]. Вопросы философии, 8, 5-17.

Correspondence concerning this paper should be addressed to Ināra Bojāre, Doctoral Student, Daugavpils University. Lìvānu 2. vidusskola, Rīgas iela 113/117, Lìvāni, LV-5316, Latvia.Email: inara.bojare@inbox.lv 